\title{
Early post-settlement habitat and diet shifts and the nursery function of tidepools during Sillago spp. recruitment in Moreton Bay, Australia
}

\author{
Nils C. Krück ${ }^{1, *}$, Craig A. Chargulaf ${ }^{1}$, Ulrich Saint-Paul ${ }^{2}$, Ian R. Tibbetts ${ }^{1}$ \\ ${ }^{1}$ Centre for Marine Studies (CMS), University of Queensland, Brisbane, Queensland 4072, Australia \\ ${ }^{2}$ Center for Tropical Marine Ecology (ZMT), Fahrenheitstr. 6, 28359 Bremen, Germany
}

\begin{abstract}
Knowledge of settlement and recruitment processes is crucial for the conservation and sustainable management of commercial fish stocks, yet for some species such information is limited. We investigated the length-frequency distribution and feeding activity of 0-group Sillago whiting on mudflats in Moreton Bay, Australia, and evaluated whether permanent intertidal residence is (1) an integral component of recruitment and (2) related to the suitability of temporary microhabitats (tidepools) as primary nursery refuges. A total of 399 whiting, comprising the 3 commercially and/or recreationally important species $S$. analis, $S$. ciliata and $S$. maculata, were collected from intertidal pools and adjacent subtidal waters during low tide. Newly settled metamorphic larvae dominated whiting assemblages in tidepools ( $>80 \%$ ) and fed almost exclusively on meiofaunal copepods and nematodes. It was only once metamorphosis was complete that new settlers joined the main juvenile population -i.e. they commenced tidal migrations, or they took up permanent residence in subtidal seagrass beds (>90\% juveniles), and shifted their diet towards macrofaunal decapods and polychaetes. During the critical first weeks after settlement, occupation of intertidal pools seemed likely to increase fitness of whiting. Specifically, the pools may provide shelter from predation, temperature-induced increases in growth and temporally extended access to intertidal meiofauna. The latter, however, appeared to vary depending on whether copepods or nematodes were the preferred prey, and whether occupied pools were isolated or interconnected. Resource and conservation managers should consider largely structureless mud- and sandflats as primary nursery zones for Sillago populations throughout their range in the Indo-Pacific.
\end{abstract}

KEY WORDS: Whiting · Nursery · Tidepool · Ontogenetic shift · Diet · Settlement · Metamorphosis · Fullness index Resale or republication not permitted without written consent of the publisher

\section{INTRODUCTION}

Shallow marine and estuarine habitats - where the settling larvae of many coastal marine teleosts congregate, complete metamorphosis and grow before moving to adult habitats elsewhere - represent what have traditionally been referred to as nurseries (see Beck et al. 2001 for review). Nurseries are thought to meet essential needs during early fish life, most notably by providing plentiful food and/or shelter from predation. Structured habitats, such as seagrass beds and mangroves, often appear to suit these requirements better than others (Laegdsgaard \& Johnson 2001, Heck et al.
2003), which is why classification schemes have been proposed to identify the nursery value of a given area or habitat explicitly in terms of its numeric contribution of recruits to adult populations, and thereby facilitate management and conservation purposes (Beck et al. 2001, Dahlgren et al. 2006). However, the ecological processes that actually advance fitness during recruitment (here, the unit of time between settlement and first spawning) and subsequent adult life may be complex and difficult to follow (see Sheaves et al. 2006). Many species, for instance, can be expected to show ontogenetic patterns of habitat use (Werner \& Gilliam 1984) that may involve successive nursery stages 
depending on local environmental conditions (e.g. Mumby et al. 2004).

Various studies worldwide have indicated that the first of such nursery stages can be shallow intertidal areas and specifically tidepools, because during low tide (LT) the latter are sometimes frequented by numerous early life stages of predominately subtidal fish species. Some detailed investigations suggest that ecologically diverse pool-dwelling species benefit from any combination of (1) temporally extended access to intertidal foods, (2) reduced predation risk and (3) temperatureinduced increases in growth during a transitional intertidal period after settlement (e.g. Norris 1963, Berghahn 1983, van der Veer \& Bergman 1986, Kneib 1994, Gibson et al. 2002). Availability of intertidal microhabitats is, in this case, likely to positively affect growth and/or survival during a highly vulnerable phase in the life history. In general, however, this perception might have arisen without direct information on whether the investigated young fish also occur subtidally and what selective advantages they accrue in intertidal pools (see Gibson \& Yoshiyama 1999). Much previous research in respect thereof and on settlement processes in general appears to have concentrated on temperate flatfishes and reef fishes.

In this study, we focused on the whiting (Sillaginidae) - one taxon among many for which information on settlement and recruitment processes is limited. Whiting are a family of epibenthic teleost fishes that are distributed throughout coastal marine and estuarine waters of the Indian and western Pacific Ocean (McKay 1992). Most are food fish of increasing importance to both commercial and recreational fisheries (McKay 1992, and see FAO fisheries database: www.fao.org/fi). In Australia, young whiting are often among the most abundant and productive fish species in shallow bays and estuaries, where they settle and grow before moving back into deeper areas at a subsequent ontogenic stage (e.g. Burchmore et al. 1988, Hyndes et al. 1997). Observations that young whiting dominate fish communities on tidal mudflats in Moreton Bay, both in intertidal pools (Crowley \& Tibbetts 1996, Meager et al. 2005) and subtidal areas (e.g. Weng 1983), led to our curiosity about settlement strategies in these habitats, which are subject to increasing human intervention. Here, we report on the length-frequency distribution and diet of 0-group Sillago spp. whiting on mudflats, hypothesising that they pass through an integral but transitional intertidal period after settlement that should be reflected by ontogenetic shifts in both of these parameters. We further analysed the feeding activity of whiting recruits in tidepools, and examined information on predator abundance and water temperature therein, in order to discuss the potential of such temporary microhabitats as primary nursery refuges.

\section{MATERIALS AND METHODS}

Study area. Moreton Bay is a large but shallow embayment situated between latitudes $27^{\circ} 04^{\prime} \mathrm{S}$ and $27^{\circ} 59^{\prime} \mathrm{S}$ in subtropical Queensland, Australia. Environmental features of the bay have comprehensively been detailed by Tibbetts et al. (1998). The fieldwork in this study was carried out on tidal flats off Dunwich, Wynnum, and Godwin Beach to cover different locations throughout the bay (Fig. 1). All locations feature muddy to sandy substrate, which is partially (intertidal) or almost fully (subtidal) covered with seagrass (Zostera spp.), and experience micro- to mesotidal conditions (tidal range $\leq 1.5 \mathrm{~m}$ ). Numerous tidepools (mostly 0.5 to $2 \mathrm{~m}$ diameter), caused by natural channels and depressions and/or stingray foraging activity, are apparent during semidiurnal LT periods. Most individual pools seem to persist for days or weeks, but some may last for months. Along with sillaginid whiting, some gobiids (Favonigobius spp.) and penaeid prawns dominate nekton communities in the pools (Crowley \& Tibbetts 1996, Meager et al. 2005).

Sampling. Sampling was conducted between 14 February and 8 June 2007. Pool-dwelling fish were caught by dip-netting ( $1 \mathrm{~mm}$ mesh size) from randomly chosen pools within $50 \times 50 \mathrm{~m}$ sample areas. At least

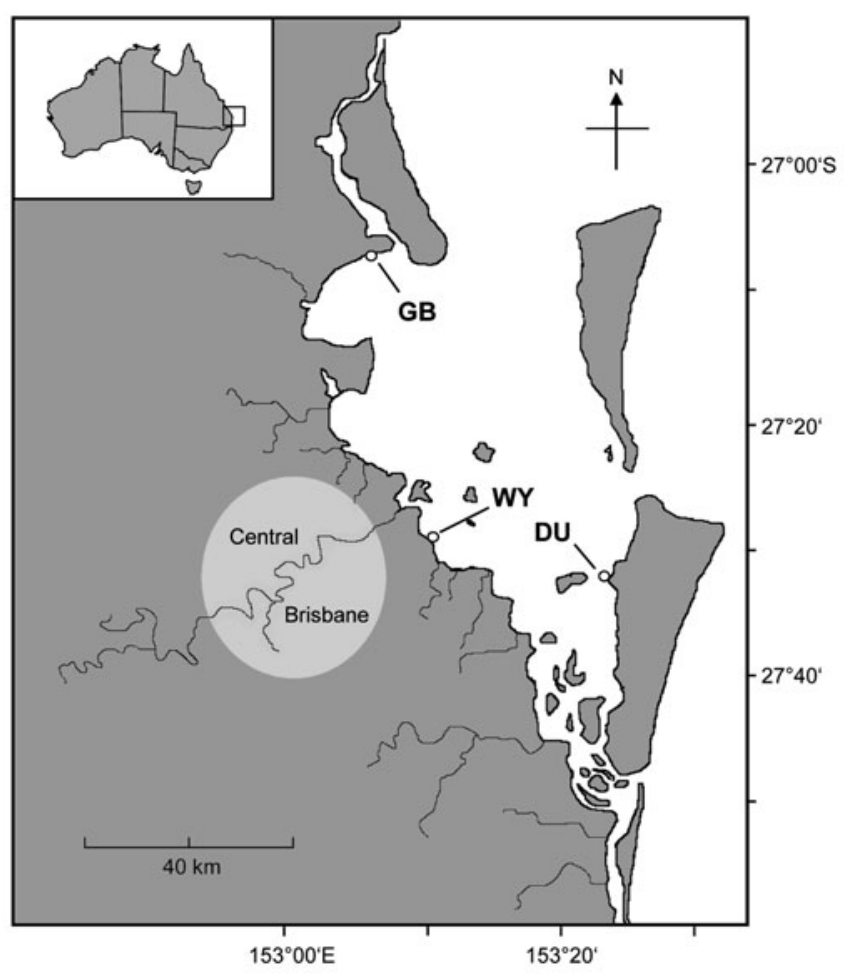

Fig. 1. Moreton Bay surrounded by the Brisbane metropolitan area in SE Queensland, Australia. The fieldwork was carried out at Dunwich (DU), Wynnum (WY) and Godwin Beach (GB) 
10 ind. were obtained $2 \mathrm{~h}$ before and after LT ( $4 \mathrm{~h}$ of pool residence) during both day (06:00 to 18:00 h) and night (18:00 to 06:00 h), respectively, at each location. Pool volumes were estimated using the method of Mahon \& Mahon (1994). Pool complexity was recorded as percentage coverage with gravel, seagrass, plant and/or animal remains. Connectivity of pools was assigned using a binary score $(0=$ isolated, $1=$ connected to an unconsidered number of other pools by small streams). Whiting in subtidal habitats were captured using a $3 \mathrm{~mm}$ square-mesh seine net $(10 \times 2 \mathrm{~m})$ operated downshore of each $50 \times 50 \mathrm{~m}$ sample area. Two net hauls were conducted parallel to the shoreline around peak LT during both day and night at each location. Net efficiency was not tested, but catch loss due to the small size of new settlers was assumed to be negligible (cf. Smith \& Sinerchia 2004). All fish were killed in an ice slurry immediately after sampling and fixed in $5 \%$ formalin/seawater until further processing. For an experiment to estimate the gastric evacuation rate (GER; Animal Ethics Certificate CMS/130/07), 42 young whiting were collected from tidepools at Dunwich in May 2007. These fish were kept alive and transported immediately to experimental aquaria at Moreton Bay Research Station (MBRS).

Laboratory procedures. Dial callipers were used to measure the standard length (SL) of fish, i.e. from the tip of the snout to the posterior edge of the caudal peduncle $( \pm 0.5 \mathrm{~mm})$. Fish were then investigated morphologically under an Olympus U-CMAD-2 stereo microscope with cold light source (Olympus LG-PS2) to classify development stages and identify species. Full development of fins and scales at a length of $>20 \mathrm{~mm}$ (cf. Weng 1983) was considered to discriminate juveniles from larvae (adults were not caught). Species were identified by investigating pigmentation patterns and external meristic characters following keys provided by Weng (1983) and McKay (1992).

All pool fish and a random selection of early juveniles from subtidal areas were analysed for stomach fullness and diet composition. Small forceps were used to excise digestive tracts and separate stomachs and intestines under a stereo microscope (see above). Stomachs were then transferred to a $1 \mathrm{ml}$ SedgwickRafter counting cell filled with filtered seawater. A fullness code (FC) based on a 5 point system, where 1 is empty and 5 is full, was assigned to each stomach prior to it being emptied of prey using fine wire needles. Stomach contents were then squashed into a corner of the cell, covered with a lid, and the volume estimated by counting filled cubes $\left(1 \mathrm{~mm}^{3}\right)$ to the nearest $0.25 \mathrm{~mm}^{3}$ (similar to methods introduced by Hellawell $\&$ Able 1971). Thereafter, contents were grouped in the diet/prey categories nematodes, polychaetes, crustaceans (subdivided into copepods, amphipods, and decapods), and unidentified. Item numbers for each category were then counted, and the volume estimated successively using the above method. Total stomach content volumes were subsequently compared to the sum of single diet category volumes, and if in disagreement, measurements were repeated.

For the GER experiment, test animals were starved for $30 \mathrm{~h}$ in a $96 \mathrm{l}$ aquarium with fresh seawater supply. Thereafter, fish were captured with dip nets, carefully transferred into each of 7 plastic jars $(11)$, and fed on a prey solution containing a mix of live zoobenthos (extracted from sediments from the natural habitat) and defrosted brine shrimp nauplii (Artemia sp.). Ad libitum feeding was stopped after $2 \mathrm{~h}$ by transferring all fish into 7 separate jars devoid of prey. One individual out of each jar was captured and killed in an ice slurry directly after feeding and in every subsequent hour ( $6 \mathrm{~h}$ in total). Fish were later analysed for stomach fullness as described. The whole experiment was conducted during daytime considering outcomes from a preliminary monitoring experiment $(7$ young whiting over $2 \mathrm{~d}$ ), which indicated 2 similar high and low points in feeding activity during the day and night cycle. The water temperature was $22^{\circ} \mathrm{C}$, corresponding to the average in subtidal shores.

Data analysis. Differences in mean fish length among tide zones and sample locations were tested using the non-parametric Mann-Whitney $(U)$ and Kruskal-Wallis (K-W) tests, respectively. The diet composition was analysed calculating the frequency of occurrence $(\% \mathrm{~F})$, percentage number $(\% \mathrm{~N})$, volume $(\% \mathrm{~V})$, and Index of Relative Importance (\%IRI; Cortes 1997) of each diet category. Ontogenetic and spatiotemporal differences in mean contribution of diet categories were tested by number and volume using the $U$-test and calculating the Bray-Curtis Index of dissimilarity (BCI; Bray \& Curtis 1957). A BCI >0.6 was considered biologically significant (e.g. Hyndes et al. 1997). Outcomes were illustrated using arcsine-transformed mean volumetric contributions of diet categories for Bray-Curtis polar ordination (Euclidean axis projection and residual distance) in PC-Ord (McCune \& Mefford 1999).

The feeding activity of whiting in tidepools was investigated after establishing a high resolution measure of stomach fullness. Three models were fitted to lengths and stomach content volumes of fish that had previously been assigned maximum fullness ( $\mathrm{FC}=5$ ), in order to predict average content volumes of a full stomach at given length. Model functions were (1) $\ln \left(V_{\mathrm{p}}+1\right)=\mathrm{a}+\mathrm{b} \ln L$ (log-linear), (2) $V_{\mathrm{p}}=\mathrm{a}+\mathrm{b} L+\mathrm{c} L^{2}$ (quadratic) and (3) $V_{\mathrm{p}}=\mathrm{a} \mathrm{e}^{\mathrm{b} L}$ (exponential growth), where $V_{\mathrm{p}}$ is the predicted stomach content volume, $L$ is the fish length, and $\mathrm{a}, \mathrm{b}$ and $\mathrm{c}$ are constants. The best fitting model was used to calculate a relative fullness 
index (RFI): RFI $=V / V_{\mathrm{p}}$, where $V$ is the observed stomach content volume (Fig. 2). Evaluation of the goodness of fit of models was based on the coefficient of determination $\left(\mathrm{r}^{2}\right)$, the standard error of the regression (SER) and residual variance (RV) subsequently expressed as natural log (lnRV).

Single and combined effects of pool residence (RES), the sample location (LoC), and day/night (DN) on stomach fullness of whiting were tested in 3- and 2-way analyses of variance (ANOVA). Since empty fish stomachs skewed RFI distribution, all ANOVAs were performed on fullness residuals $\left(\mathrm{RFI}_{r}\right.$; Fig. 2), which had previously been tested for normality and homoscedasticity using the Shapiro-Wilks and Brown \& Forsyth tests, respectively. Significances of main effects were crosschecked applying the K-W and $U$-tests to both RFI and initial FC values. Impact of the volume, complexity and connectivity of pools on RFI after $4 \mathrm{~h}$ of residence was tested using the $U$-test. For this, volumes and complexities of pools had previously been categorised into 2 groups based on means.

Models for the 3 most common patterns of gastric evacuation in fish, i.e. a linear, a square-root and an exponential model (Bromley 1994), were applied to estimate the GER (RFI decrease over time) using weighted least-square regression (weights: reciprocal standard error $\left[\mathrm{SE}^{-1}\right]$ of means). The best fitting model (see evaluation above, this section) was used to compute a feeding activity coefficient $\left(\mathrm{C}_{\mathrm{f}}\right)$ during pool residence at each location: $\mathrm{C}_{\mathrm{f}}=T_{\text {res }}-T_{\triangle \mathrm{RFI}} \times \alpha$, where $T_{\text {res }}$ is the duration in $\mathrm{h}$ of pool residence, $T_{\triangle \mathrm{RFI}}$ is the duration in $\mathrm{h}$ necessary to evacuate observed mean RFI $2 \mathrm{~h}$ before LT $\left(\mathrm{RFI}_{0}\right)$ to observed mean RFI $2 \mathrm{~h}$ after LT $\left(\mathrm{RFI}_{1}\right)$, and $\alpha$ is a balancing factor of 0.75 . Given that $\mathrm{RFI}_{0}$ was higher than $\mathrm{RFI}_{1}$ at each sample location, values for $\mathrm{C}_{\mathrm{f}}$

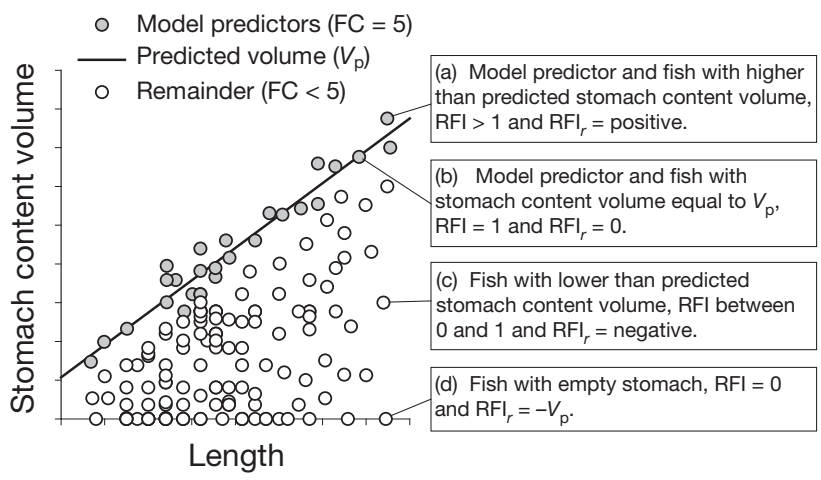

Fig. 2. Example of stomach fullness estimation. Lengths and stomach content volumes of fish that had previously been assigned maximum fullness (fullness code, FC $=5$ ) were used to predict average content volumes of a full stomach at given length. Predicted volumes $\left(V_{\mathrm{p}}\right)$ were used to calculate a relative fullness index $\left(\mathrm{RFI}=V / V_{\mathrm{p}}\right.$ and fullness residuals $\left(\mathrm{RFI}_{\mathrm{r}}=\right.$ $V-V_{\mathrm{p}}$ ). Data are exemplary; points a, b, c and d are marked to explain value ranges (see boxes) near 0 gave no indication for significant food intake during pool residence $\left(T_{\text {res }} \approx T_{\triangle \mathrm{RFI}}\right)$. The closer $\mathrm{C}_{\mathrm{f}}$ got to $4\left(T_{\Delta \mathrm{RFI}} \rightarrow 0\right)$, the more feeding was assumed to have occurred. The factor $\alpha$ was included to account for variable water temperatures in tidepools (sometimes $>10^{\circ} \mathrm{C}$ higher than experimental/subtidal conditions, cf. Birt \& Tibbetts 2007) and their effects on the duration of food processing. To estimate $\alpha$, we assumed on average $5^{\circ} \mathrm{C}$ warmer tidepool waters and a presumably conservative $Q_{10}$ of 2 after Rombough (1997).

\section{RESULTS}

Three species of whiting were identified in both intertidal pools and subtidal shores: the golden-lined whiting Sillago analis Whitley, 1934, the sand whiting $S$. ciliata Cuvier, 1829, and the trumpeter whiting $S$. maculata Quoy \& Gaimard, 1824. However, discriminating between larvae and early juveniles of these species proved to be very difficult. The majority of larvae could be identified to genus only. Even regarding fully metamorphosed fish, discrimination between the 2 sibling species $S$. analis and $S$. ciliata was hampered due to yet undifferentiated pigmentation and a natural overlap of 2 in the number of lateral line scales (McKay 1992). To directly consider species identities in subsequent analyses was thus impeded. Nevertheless, discrimination of juvenile $S$. maculata from either of the other 2 species by counting anal fin soft rays revealed that whiting assemblages in subtidal shores at both Dunwich and Wynnum were dominated by this species (94.2\% out of 156 and $90.2 \%$ out of 41 distinguished fish, respectively). In contrast, the total of 4 fish collected from subtidal shores at Godwin Beach were all either $S$. analis or $S$. ciliata.

\section{Length-frequency distribution}

Whiting assemblages in tidepools (9 to $41 \mathrm{~mm}$ ) were dominated by larvae $(81.9 \%)$. Early juveniles $(\leq 30 \mathrm{~mm}$, with 2 exceptions) accounted for the remainder $(18.1 \%)$. In subtidal shores, whiting assemblages (11 to $132 \mathrm{~mm}$ ) were dominated by juveniles $(90.6 \%)$. Larvae accounted for the remainder $(9.4 \%)$. Due to the clear dominance of either larvae or juveniles, fish length in subtidal shores (mean $\pm \mathrm{SD}, 35.3 \pm 16.6 \mathrm{~mm}$ ) was significantly greater than in tidepools $(16.1 \pm 5.5 \mathrm{~mm}$; $<<$ $0.001, U$-test). Since the mean fish length in pools and subtidal shores did not differ significantly among sample locations ( $p>0.05, \mathrm{~K}-\mathrm{W}$ test), this observation was spatially consistent at $\mathrm{p}<0.01$ (U-test; Table 1 ). Histograms of pooled data demonstrated that pools were occupied predominately by new recruits $<19 \mathrm{~mm}$. 
Table 1. Sillago spp. Length range, mean standard length (SL), sample size (n), and percentage number (\%) of larvae and juveniles (\%) in tidepools and subtidal shores, respectively, at 3 different locations in Moreton Bay

\begin{tabular}{|lccrr|}
\hline \multirow{2}{*}{ Location } & \multicolumn{2}{c}{ SL $(\mathrm{mm})-\mathrm{n}$} & $\%$ \\
\cline { 2 - 3 } & Range & Mean $\pm \mathrm{SD}$ & & \\
\hline Intertidal pools & & & & \\
Dunwich & $10-41$ & $17.6 \pm 6.7$ & 46 & 73.9 \\
Wynnum & $10-33$ & $15.1 \pm 4.8$ & 56 & 89.3 \\
Godwin Beach & $9-26$ & $15.9 \pm 4.5$ & 42 & 81.0 \\
Total & $9-41$ & $16.1 \pm 5.5$ & 144 & 81.9 \\
Subtidal shores & & & & \\
Dunwich & $11-132$ & $35.7 \pm 15.3$ & 161 & 94.4 \\
Wynnum & $17-101$ & $34.6 \pm 21.1$ & 48 & 75.0 \\
Godwin Beach & $22-36$ & $29.3 \pm 6.1$ & 4 & 100.0 \\
Total & $11-132$ & $35.3 \pm 16.6$ & 213 & 90.6 \\
& & & & \\
\hline
\end{tabular}

Early juveniles $>26 \mathrm{~mm}$ were more than twice as frequent in permanently immersed areas (Fig. 3a). Only fish between 19 and $26 \mathrm{~mm}$, i.e. particularly those that had recently completed metamorphosis, were equally frequent in both zones (Fig. 3b).

\section{Diet composition}

A total of 169 young whiting (9 to $42 \mathrm{~mm}$ ) was investigated for diet composition. Crustaceans were the most frequently encountered prey $(100 \%)$, contributing the greatest fractions to both total prey number $(55.9 \%)$ and volume $(54.0 \%)$. Copepods (almost exclusively harpacticoids) were the dominant taxon within this category. Nematodes were encountered in 58.6\% of stomachs, accounting for $38.8 \%$ and $18.1 \%$ of the total prey number and volume, respectively. Polychaetes were comparatively rare $(13.2 \%)$ and very low in number $(0.2 \%)$, but accounted for $21.2 \%$ of the total prey volume due to their large size. Unidentified prey items (mostly highly digested) were present in 30.2\% of stomachs and were usually low in both relative number $(5.1 \%)$ and volume $(6.7 \%)$.

\section{Size-dependent shifts}

Meiofauna (i.e. copepods and nematodes) was the dominant prey of larvae, while its importance appeared to decrease in favour of macrofauna (i.e. decapods and polychaetes) in the diet of early juveniles (Table 2). The frequency of nematodes, for instance, decreased from $71.4 \%$ in the stomachs of larvae to $37.5 \%$ in those of early juveniles. Copepods were equally frequent (84.8 versus $85.9 \%)$, even though both nematodes and copepods decreased in

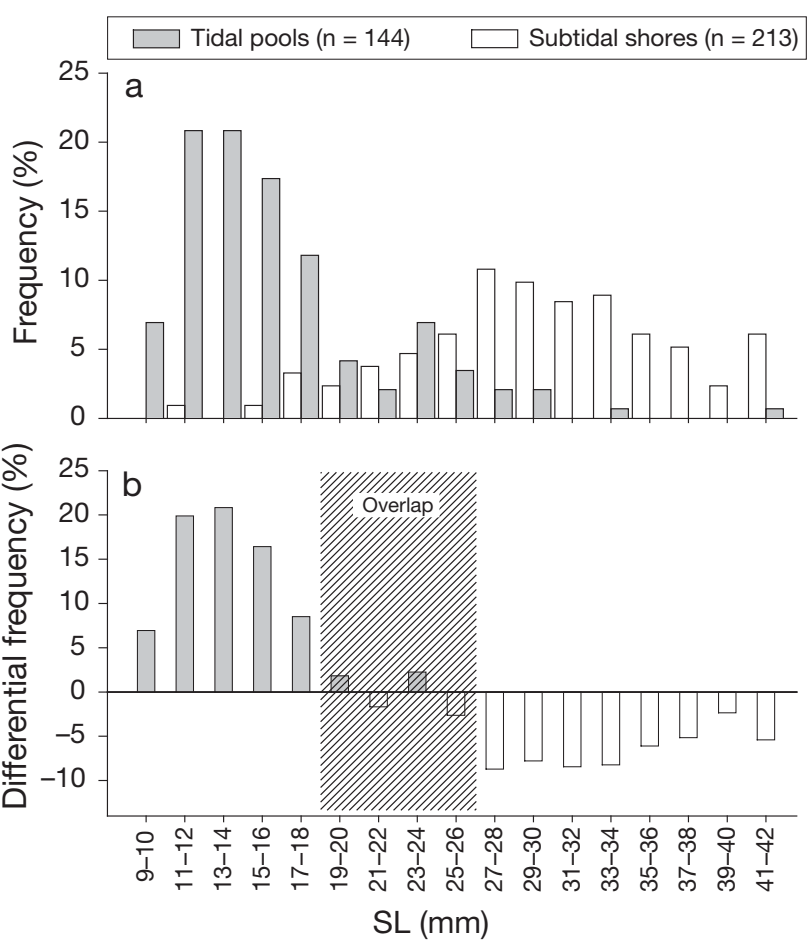

Fig. 3. Sillago spp. Length-frequency distribution in intertidal pools and adjacent subtidal shores in Moreton Bay. (a) Frequency relative to total numbers. (b) Differential relative frequency with values near 0 indicating equal proportions (signs are reversible). Fish between 43 and $132 \mathrm{~mm}$ standard length (SL), which accounted for the remaining $20.2 \%$ of total numbers in subtidal shores, are not considered

terms of volume from 36.5 to $9.1 \%$ (p $<0.01, U$-test) and from 45.1 to $19.7 \%$ ( $\mathrm{p}=0.13, U$-test), respectively. Comparatively large macrofauna showed the opposite trend. Decapods did not feature in the diet of any larva, while they were encountered in $32.8 \%$ of early juveniles, contributing $30.1 \%$ to the total prey volume. Polychaetes were encountered in $4.8 \%$ of larvae and in $26.6 \%$ of early juveniles. A similar increase was apparent in terms of their volume (5.1 versus $30.0 \%, \mathrm{p}<$ $0.001, U$-test). A diet shift was also apparent comparing the relative IRI of prey categories, although this was less obvious due to the prevailing numerical dominance of copepods and nematodes in the diet of early juveniles. However, even if 1 or 2 orders of magnitude lower, the mean numerical contribution of diet categories differed at the same significance levels as the mean volumetric contribution (Table 2 ).

Comparing the frequency and percentage volume of diet categories among larvae and 2 length classes of early juveniles indicated that the importance of macrofauna increased gradually after metamorphosis. The contribution of amphipods (of intermediate size) revealed no clear trend, but may be highest during the transition period (Fig. 4). 
Variation with sample location and species

The diet of whiting larvae at Dunwich and Wynnum consisted predominately of copepods, which were encountered in $>97 \%$ of investigated stomachs, contributing $>77 \%$ to the total prey volume. At Godwin Beach, nematodes were present in all stomachs $(100 \%)$ and accounted for $>67 \%$ of the total prey volume. This spatial difference in major diet components was significant in terms of both number and volume ( $p<0.001, U$-test). Accordingly, the BCI was $>0.85$ comparing volumetric diet compositions of larvae at Godwin Beach to those at either Dunwich or Wynnum (Fig. 5). A significant difference in diet composition of pool-dwelling fish $2 \mathrm{~h}$ before and after LT, respectively, was not apparent at either of the sample locations ( $p>0.05, U$-test).

Spatial differences in diet composition among early juveniles were not as prominent $(\mathrm{BCI}<0.6)$. Volumetrically, the most important diet categories at Duwnich were polychaetes $(31.3 \%)$, followed by decapods $(27.1 \%)$ and copepods $(21.0 \%)$. At Wynnum, decapods were most important $(41.3 \%)$, followed by copepods $(23.4 \%)$ and polychaetes $(20.1 \%)$. Nematodes $(35.9 \%)$ and polychaetes $(32.6 \%)$, followed by decapods $(11.7 \%)$, were volumetrically important at Godwin Beach (Fig. 5).

Interspecific dietary variation could only be addressed with caution due to persisting problems with the accurate discrimination of whiting species. Across all locations, we found that early juvenile Sillago maculata $(\mathrm{n}=32)$ ingested significantly more copepods ( $\mathrm{p}<0.05, U$-test) and significantly fewer nematodes ( $\mathrm{p}<0.01, U$-test) than $S$. analis/ciliata (i.e. $S$. analis and/or $S$. ciliata, $\mathrm{n}=21$ ). Expressed in terms of contributions to the total, the underlying differences (S. maculata versus $S$. analis/ciliata) were: copepods93.2 versus $35.6 \%$ (number) and 36.0 versus $10.1 \%$ (volume); nematodes - $2.7 \%$ versus $61.3 \%$ (number) and $0.2 \%$ versus $14.0 \%$ (volume).

\section{Feeding activity in tidepools}

\section{Estimation of the RFI and GER}

Least-square regressions for all models applied to estimate the RFI were significant at $p<0.001$. The exponential model yielded the highest $r^{2}(0.95)$. Outcomes for the quadratic model were very similar $\left(\mathrm{r}^{2}=\right.$ 0.94), even if this model clearly failed to predict meaningful stomach content volumes at low fish lengths. The log-linear model yielded a slightly lower $\mathrm{r}^{2}$ (0.89), but markedly reduced SER and RV (Table 3). Considering all 3 evaluation criteria and that neither the quadratic nor the exponential model revealed normally distributed residuals ( $p<0.01$ ), the linear model (Fig. 6) was preferred in order to calculate the RFI of whiting.

A total of 27 out of 42 whiting (15 to $33 \mathrm{~mm}$ ) provided $\geq 3$ observations of the RFI at each of 7 time intervals in order to estimate the GER. The remaining fish were

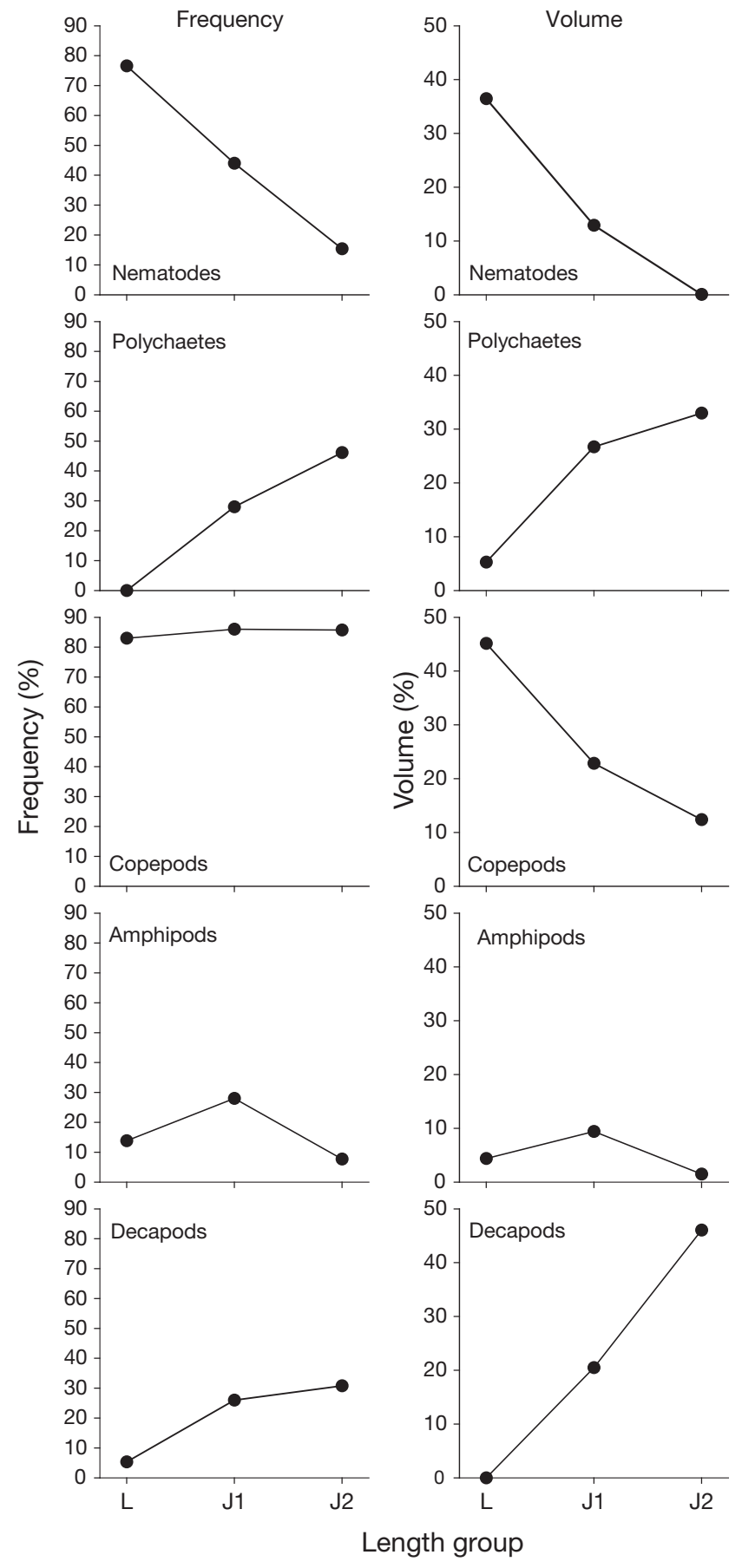

Fig. 4. Sillago spp. Percentage frequency (left) and volume (right) of prey categories in the diet of larvae $(\leq 20 \mathrm{~mm}, \mathrm{n}=$ $105)$ and the juvenile length classes $1(\mathrm{~J} 1,21$ to $30 \mathrm{~mm}, \mathrm{n}=50)$ and $2(\mathrm{~J} 2,31$ to $42 \mathrm{~mm}, \mathrm{n}=14)$ 


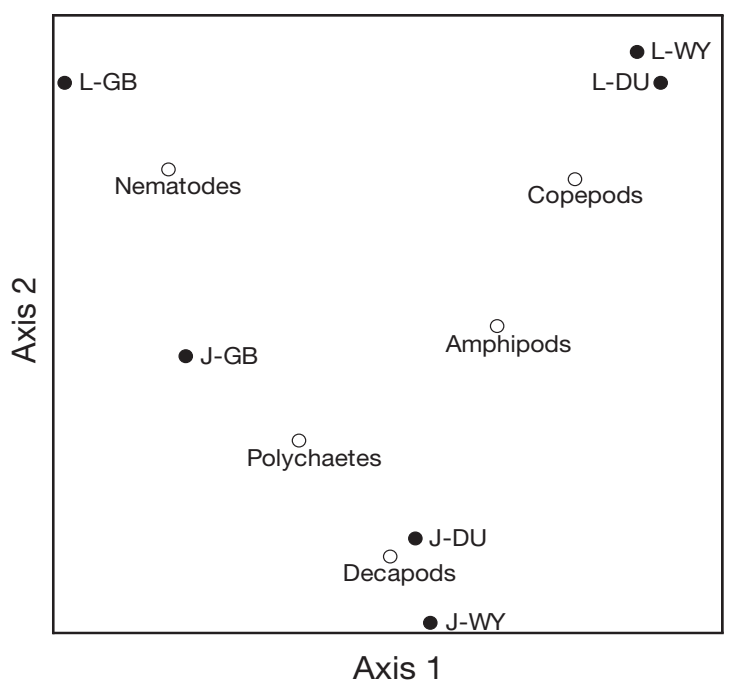

Fig. 5. Sillago spp. Bray-Curtis polar ordination of the mean volumetric contribution of prey categories $(\mathrm{O})$ to the diet of larvae (L) and early juveniles (J) (•) at Dunwich (DU),

Wynnum (WY) and Godwin Beach (GB) in Moreton Bay

either too weak to feed or succumbed to stress and died during the processes of capture, transfer, and starvation. The RFI decreased from an initial $0.76 \pm 0.19$ at $t_{0}$ to $0.18 \pm 0.08$ after $6 \mathrm{~h}$ of starvation (means $\pm \mathrm{SD}$ ). All 3 models provided highly significant approximations to the data $(p<0.001)$. A slightly higher $r^{2}$, and slightly lower SER and RV, favoured application of the squareroot model (Table 4) to calculate $T_{\triangle \mathrm{RFI}}$. The model (Fig. 7) indicated that the GER of young whiting depends on stomach fullness.

\section{Temporal and spatial effects}

Residence in tidepools and the sample location, but not day/night, proved to be significant factors in a 3-way ANOVA to test for the respective effects of RES, LOC, and DN on stomach fullness of whiting. However, all 3 factors
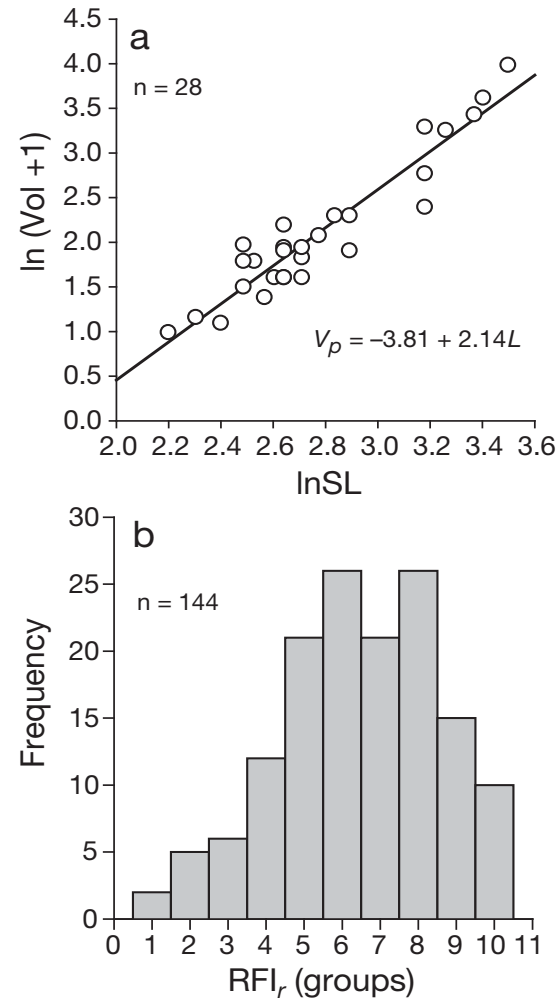

Fig. 6. Sillago spp. (a) Log-linear model applied to estimate the RFI. Model equation with $r^{2}=0.89(p<0.001)$ is given beneath the fit. (b) Histogram of resulting fullness residuals $\left(\mathrm{RFI}_{r}\right)$ calculated for the total of investigated pool-dwelling fish ( $\mathrm{p}>0.05$, Shapiro-Wilks test)

showed a significant interaction $(\mathrm{p}<0.01)$. Subsequent 2-way ANOVAs revealed that RES affected stomach fullness significantly at both Dunwich and Wynnum $(\mathrm{p}<$ 0.001 , Table 5), where the RFI was usually much higher $2 \mathrm{~h}$ before $\mathrm{LT}$ (mean $\pm \mathrm{SD}, 0.68 \pm 0.24$ and $0.59 \pm 0.30$, respectively) than $2 \mathrm{~h}$ after LT $(0.11 \pm 0.18$ and $0.17 \pm 0.27$, respectively), regardless of whether it was day or night (Fig. 8). In contrast, stomach fullness at Godwin Beach varied significantly in interactive force of the 2 factors RES and DN only ( $p<0.001$, Table 5, Fig. 8).

Table 2. Sillago spp. Frequency of occurrence $(\% \mathrm{~F})$, percentage number $(\% \mathrm{~N})$, volume $(\% \mathrm{~V})$, and Index of Relative Importance (\%IRI) of diet categories in stomachs of larvae ( 9 to $20 \mathrm{~mm} ; \mathrm{n}=105$ ) and early juveniles (21 to $42 \mathrm{~mm} ; \mathrm{n}=64$ ). Probability (p) refers to the Mann-Whitney $U$-test comparing means by both numeric and volumetric contribution (ns: not significant with $p>0.05$ ). $(-)$ Not present (not tested)

\begin{tabular}{|c|c|c|c|c|c|c|c|c|c|}
\hline \multirow[t]{2}{*}{ Category } & \multicolumn{4}{|c|}{ Larvae } & \multicolumn{4}{|c|}{ Early juveniles } & \multirow[t]{2}{*}{$\mathrm{p}$} \\
\hline & $\% \mathrm{~F}$ & $\% \mathrm{~N}$ & $\% \mathrm{~V}$ & $\%$ IRI & $\% \mathrm{~F}$ & $\% \mathrm{~N}$ & $\% \mathrm{~V}$ & $\%$ IRI & \\
\hline Nematodes & 71.4 & 38.8 & 36.5 & 33.0 & 37.5 & 38.7 & 9.1 & 12.5 & $<0.01$ \\
\hline Polychaetes & 4.8 & 0.1 & 5.1 & 0.2 & 26.6 & 0.4 & 30.0 & 5.6 & $<0.01$ \\
\hline Crustaceans & 100.0 & 54.0 & 49.4 & 63.5 & 100.0 & 59.7 & 56.9 & 81.0 & - \\
\hline Copepods & 84.8 & 53.8 & 45.1 & 63.1 & 85.9 & 57.4 & 19.7 & 68.5 & ns \\
\hline Amphipods & 13.3 & 0.2 & 4.3 & 0.4 & 23.4 & 1.6 & 7.0 & 2.1 & ns \\
\hline Decapods & - & - & - & - & 32.8 & 0.7 & 30.1 & 10.4 & $<0.01$ \\
\hline Unidentified & 33.3 & 7.2 & 9.1 & 3.3 & 25.0 & 1.3 & 4.1 & 0.9 & ns \\
\hline
\end{tabular}


Based on the GER model, no food intake was necessary to explain significantly different mean RFI of whiting at the beginning and end of tidepool residence at Dunwich $\left(C_{f}=-0.7\right)$. Outcomes for whiting at Wynnum were similar, but some feeding in pools was probable $\left(C_{f}=0.6\right)$. In contrast, generally nonsignificant differences between $\mathrm{RFI}_{0}$ and $\mathrm{RFI}_{1}$ at Godwin Beach indicated that young whiting fed almost continuously $\left(C_{f}=3.5\right)$.

\section{Effects of pool characteristics}

Volumes of pools sampled $2 \mathrm{~h}$ after LT ranged between an estimated 0.0019 and $0.0458 \mathrm{~m}^{3}$ (mean $\approx$ $8.5 \mathrm{dm}^{3}$ ). Fish from pools with a volume $<8.5 \mathrm{dm}^{3}$ showed a lower $\mathrm{RFI}_{1}$ (mean $\pm \mathrm{SD}, 0.25 \pm 0.33$ ) than

Table 3. Goodness of fit of 3 models used to predict average content volumes of full stomachs of young Sillago whiting at given length $\left({ }^{*} \mathrm{p}<0.001\right)$. SER: standard error of the regression; RV: residual variance

\begin{tabular}{|lccr|}
\hline Type & \multicolumn{3}{c|}{ Evaluation criteria } \\
& $\mathrm{r}^{2}$ & SER & $\operatorname{lnRV}$ \\
\hline Log-linear & $0.892^{*}$ & 0.261 & -2.726 \\
Quadratic & $0.942^{*}$ & 3.053 & 2.155 \\
Exponential & $0.954^{*}$ & 2.676 & 1.931 \\
\hline
\end{tabular}

Table 4. Goodness of fit of 3 models used to estimate the gastric evacuation rate of young Sillago whiting from a starvation experiment $\left({ }^{*} p<0.001\right)$. Abbreviations as in Table 3

\begin{tabular}{|lccc|}
\hline \multirow{2}{*}{ Type } & \multicolumn{3}{c|}{ Evaluation criteria } \\
& $\mathrm{r}^{2}$ & SER & $\operatorname{lnRV}$ \\
\hline Linear & $0.965^{*}$ & 0.172 & -6.276 \\
Square-root & $0.975^{*}$ & 0.146 & -6.360 \\
Exponential & $0.962^{*}$ & 0.181 & -5.833 \\
\hline
\end{tabular}

Table 5. Results of 2-way ANOVAs (df $=1$ ) to test for single and combined effects of tidepool residence (RES) and day/night (DN) on stomach fullness of young Sillago whiting at 3 different locations in Moreton Bay (SS: mean sum of squares; ns: not significant with $\mathrm{p}>0.05$ )

\begin{tabular}{|llccc|}
\hline Location & Source & SS & $F$ & $\mathrm{p}$ \\
\hline Dunwich & RES & 9.15 & 27.07 & $<0.001$ \\
& DN & 0.45 & 1.34 & $\mathrm{~ns}$ \\
& RES $\times$ DN & 0.01 & 0.01 & $\mathrm{~ns}$ \\
Wynnum & RES & 7.92 & 18.15 & $<0.001$ \\
& DN & 0.86 & 1.96 & $\mathrm{~ns}$ \\
& RES $\times$ DN & 0.41 & 0.93 & $\mathrm{~ns}$ \\
Godwin & RES & 0.31 & 0.88 & $\mathrm{~ns}$ \\
Beach & DN & 0.48 & 1.36 & $\mathrm{~ns}$ \\
& RES $\times$ DN & 6.73 & 19.35 & $<0.001$ \\
& & & & \\
\hline
\end{tabular}

those from pools above the average volume $(0.39 \pm$ 0.41 ), although the difference was not significant $(\mathrm{p}>$ 0.05 , $U$-test). Similar findings resulted from investigating the effects of pool complexity, which ranged between 0 and $90 \%$. The $\mathrm{RFI}_{1}$ of fish from pools less complex than an average $23 \%(0.24 \pm 0.31)$ was lower compared that of fish from pools of greater $(>23 \%)$

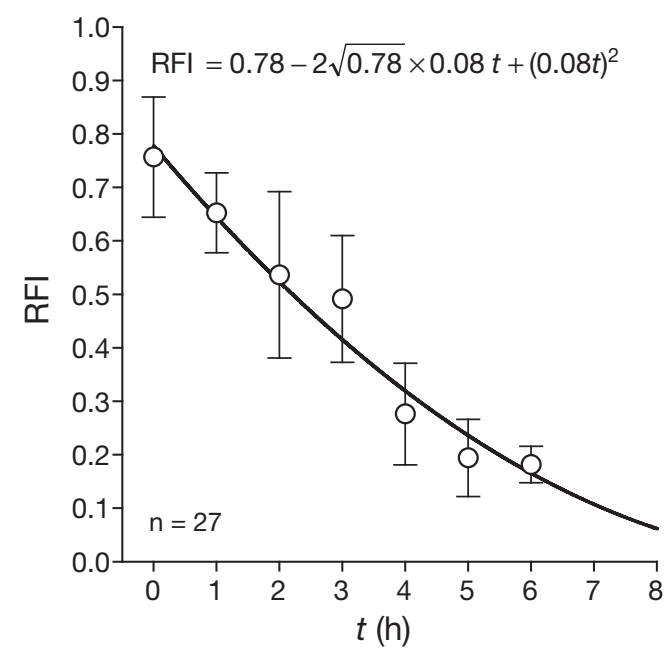

Fig. 7. Sillago spp. Decrease in relative fullness index (RFI) over time (mean $\pm \mathrm{SE}$ ) during a starvation experiment to estimate the gastric evacuation rate. The fit illustrates a squareroot model after Bromley (1994) $\left(\mathrm{r}^{2}=0.98, \mathrm{p}<0.001\right)$. The model equation is given above the fit

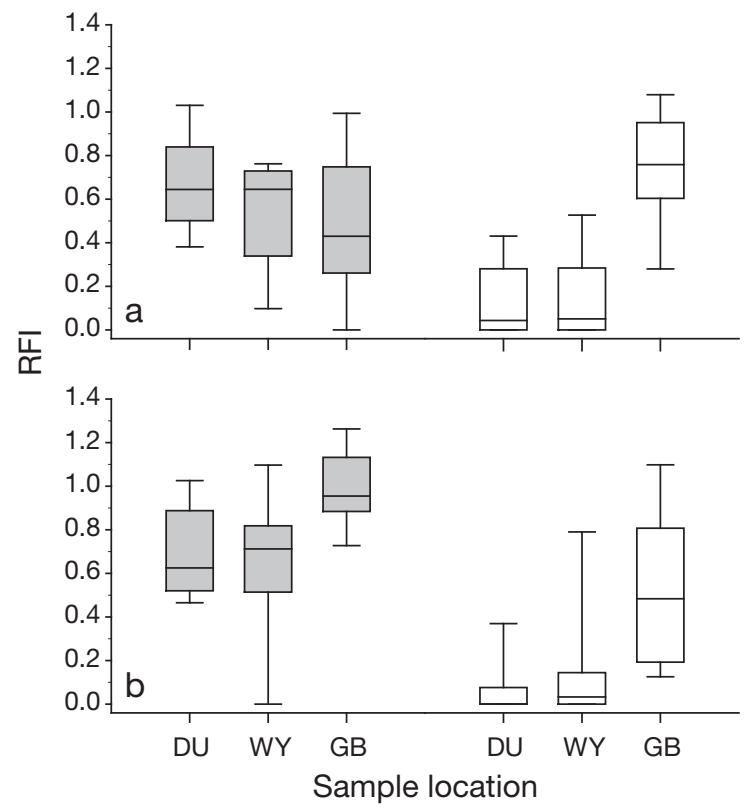

Fig. 8. Sillago spp. Median RFI including 25th/75th (boxes) and 10th/90th (bars) percentiles $2 \mathrm{~h}$ before and after low tide (grey and white, respectively) in tidepools in Moreton Bay ( $\mathrm{n}=144$, with $\mathrm{n} \geq 10$ per group). Results during (a) day and (b) night in Dunwich (DU), Wynnum (WY) and Godwin Beach (GB) are shown 


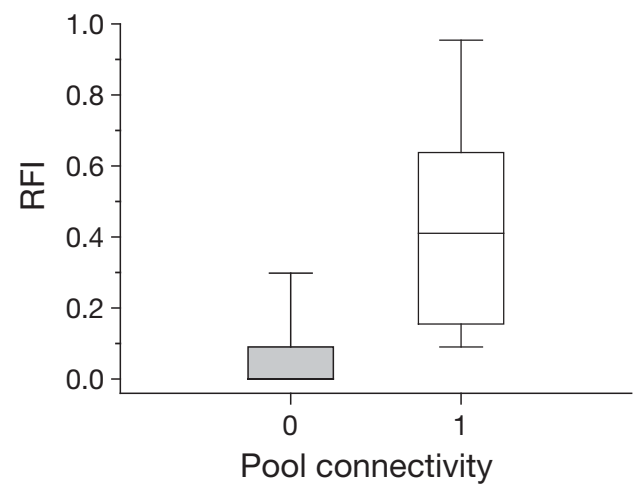

Fig. 9. Sillago spp. Median RFI including 25th/75th (boxes) and 10th/90th (bars) percentiles after residence in isolated $(0$, grey, $\mathrm{n}=34$ ) and connected $(1$, white, $\mathrm{n}=17$ ) tidepools in Moreton Bay

complexity $(0.31 \pm 0.38)$, but again the difference was not significant ( $p>0.05, U$-test). Effects of pool connectivity, in contrast, appeared to be important. Fish sampled $2 \mathrm{~h}$ after LT from connected tidepools showed a significantly higher $\mathrm{RFI}_{1}(0.44 \pm 0.34)$ than those from isolated pools $(0.09 \pm 0.17, \mathrm{p}<0.01, U$-test; Fig. 9$)$. Subsequent consideration of the relative number of fish sampled from connected pools at different locations revealed: Godwin Beach (100\%), Wynnum (25\%), and Dunwich $(0 \%)$. However, these values represent only $50 \%$ (Godwin Beach), $70 \%$ (Wynnum), and $52 \%$ (Dunwich) of the data, because pool connectivity was first recorded after potential impacts on the feeding activity of whiting had been recognised in the field.

\section{DISCUSSION}

Post-settlement changes in distribution and diet indicate that permanent intertidal residence represents an integral component of Sillago spp. recruitment in the investigated habitats. Metamorphic larvae consistently congregated in intertidal pools, while juveniles predominated in adjacent subtidal waters. Considering that very recently metamorphosed fish were equally frequent in both zones, it appears that new settlers do not fully join the main juvenile population until they ultimately complete metamorphosis. The isochronic beginning of a shift in diet from meiofauna to macrofauna further supports this idea. Several Sillago species, including all those investigated, exhibit diet shifts during post-settlement ontogeny (e.g. McLean 1971, Gunn \& Milward 1985, Burchmore et al. 1988). Commonly, these shifts appear to coincide with a habitat shift, even though previous studies usually referred to migrations by older whiting to adult habitats in deeper waters (e.g. Robertson 1977, Burchmore et al. 1988, Hyndes et al. 1997). However, diet shifts may occur abruptly 3 or 4 times during fish ontogeny and, in many cases, are not only associated with but even caused by shifts in habitat use (Werner \& Gilliam 1984). Two studies, investigating the diet of early juvenile $S$. maculata from the study area, proposed meiofauna to be equal in proportion to and completely replaced by larger macrofauna at a length of $30 \mathrm{~mm}$ (fork length) and >40 mm (SL), respectively (Coull et al. 1995, Mangubhai et al. 1998). We suggest a presumably n-dimensional niche shift to occur at $\sim 20 \mathrm{~mm}$ SL, a length when young sillaginids in the investigated habitats have ultimately completed metamorphosis, begin to change their diet, and start tidal migrations or move permanently to subtidal seagrass beds, which serve as juvenile nurseries for the same and other Sillago species elsewhere in Australia (e.g. Robertson 1977, Burchmore et al. 1988, Smith \& Sinerchia 2004). Presumably, these shifts are completed over a length-range of several $\mathrm{mm}$. The dietary contribution of macrofauna relative to meiofauna, for instance, appeared to increase gradually from $20 \mathrm{~mm}$ on and may reach $100 \%$ some time after whiting attain $40 \mathrm{~mm}$ (Coull et al. 1995). Similarly, increased subtidal abundance during LT started at roughly $19 \mathrm{~mm}$, and an exceptionally large individual of $41 \mathrm{~mm}$ indicated the length-boundary after which whiting are absent from pools. Despite this fairly clear agreement, it is conceivable that the low relative frequency of juveniles in pools was biased by the use of dip nets for sampling. However, we assume that the opposite is more likely. That is, the frequency of juveniles relative to larvae may have been slightly overestimated, because larger and more agile juveniles were much easier to detect than small and almost transparent larval forms, even though the former were usually slightly harder to catch. Still, targeted sampling of pools close to the LT mark would probably yield a greater proportion of juveniles (cf. Hernández et al. 2002).

Metamorphosis, as the transformation into a morphologically and functionally different adult phenotype, is referred to by many as the 'critical period' (Thorisson 1994). Settling whiting are therefore likely to face environmental requirements and constraints other than their post-metamorphic relatives. A transitional intertidal period after settlement must consequently be considered to allow for a more favourable balance in the trade-off between growth and survival than tidal migrations or permanent residence in subtidal areas. Indeed, first observations of the transforming larvae of predominately subtidal fish species in intertidal pools date back to the 1960s (Norris 1963, Gosline 1965) or earlier. Even more generally, it appears that the importance of metamorphosis for early post-settlement performance has received relatively little attention, given that mortality during this time 
may be significant in regulating natural population levels (van der Veer 1986, Victor 1986, Caselle 1999). Previous research in this direction seems to have focused on specific groups, such as temperate flatfishes and reef fishes (see e.g. McCormick et al. 2002 and references therein). Some of the former exhibit recruitment mechanisms similar to that of sillaginids in the study area (Berghahn 1983). Plaice Pleuronectes platessa, for instance, settle from offshore waters onto sandflats in the North Sea, complete metamorphosis while occupying tidepools, start tidal migrations and, from then on, move gradually into deeper waters (van der Veer \& Bergman 1986, Gibson et al. 2002). Members of the reef fish families Pomacentridae, Acanthuridae, Serranidae, Sparidae and Labridae appear to show similar behaviour in rocky intertidal environments of Hawaii, South Africa and Barbados (e.g. Gosline 1965, Beckley 1985, 2000, Mahon \& Mahon 1994). Several studies on seachubs and the mummichog Fundulus heteroclitus in different regions of the Americas provide good examples for other taxa (e.g. Norris 1963, Kneib 1994). Overall, however, it appears that a primary nursery function of intertidal pools varies with location and/or species and is seldom firmly established (see Gibson \& Yoshiyama 1999).

\section{Suitability of tidepools as temporary nurseries}

The young of various fish species worldwide enter inundated intertidal habitats for feeding. Tidepool occupation may enable the youngest representatives of some of these species to extend otherwise limited times to access intertidal foods as long as conditions (e.g. water temperature and depth) are tolerable. This has previously been suggested at least to benefit pooldwelling metamorphic flatfishes in the Wadden Sea (Berghahn 1983, van der Veer \& Bergman 1986). At 2 out of 3 locations in our study (i.e. Dunwich and Wynnum), however, whiting generally appeared to feed outside of pools. Even assuming that $\mathrm{C}_{\mathrm{f}}$ was biased, foremost by using an officially limited number of highly vulnerable fish for the GER experiment, and by estimating effects of variable water temperatures on the duration of food processing, field data per se do not indicate otherwise. That is, evacuation of 42 to $57 \%$ of stomach contents to $\mathrm{RFI}_{1}$ values of 0.11 (Dunwich) and 0.17 (Wynnum) over $4 \mathrm{~h}$ of pool residence does not seem to reflect significant food intake. Considering laboratory experiments by Coull et al. (1995) on Sillago maculata, the young whiting may have depleted meiofauna over relatively short time periods. Firstly, however, field evidence of such a scenario (e.g. Kneib 1994) generally refers to controlled microcosm settings (see Coull 1999 for more references). Secondly, this situation would have revealed higher $\mathrm{RFI}_{1}$ values. We therefore assume that accessible prey in the mostly small and isolated tidepools at Dunwich and Wynnum was limited to begin with. A robust bioenergetics model would help to resolve whether pool occupation at these locations could nevertheless be of indirect energetic benefit (e.g. if tidal migrations are associated with substantial metabolic costs but little further energetic gain).

The situation for whiting in tidepools at Godwin Beach was different, as it appeared to involve almost continuous feeding. It is unlikely that this was a result of differences in volume or complexity of sampled pools, since no impact on stomach fullness was apparent at either location. On the contrary, pool connectivity appeared to have an impact. Since most tidepools at Godwin Beach were at least locally connected, it is conceivable that increased feeding activity at this location resulted from access to a wider range of sediment types containing different densities and compositions of meiofauna (Giere 1993). The feeding arena may then provide not only more meiofauna, but also access to meiofauna that is more likely to be consumed. However, it is particularly important to consider that the diet of whiting at Godwin Beach was dominated by nematodes and not by copepods, such as at Dunwich and Wynnum. Mean relative proportions of these 2 taxa in pool sediments (first $1.5 \mathrm{~cm}$ ) appeared to be similar across locations (65 to $75 \%$ nematodes), and highest absolute numbers of both were found in the muddiest sediments at Wynnum (authors' unpubl. data). Presumably therefore, pools at different sample locations were dominated by different Sillago species. This and other studies indicate that copepods are a major resource for young $S$. maculata, while this is less obvious regarding S. analis/ciliata (cf. Coull et al. 1995, Mangubhai et al. 1998). Dominance of $S$. maculata in tidepools at Dunwich and Wynnum (>90\% in subtidal shores) could explain the preference for copepods over much more abundant nematodes, which, in turn, is likely to have impacted the feeding activity in few to no connected tidepools at these locations. Random feeding or preference for nematodes by larvae in the many connected tidepools at Godwin Beach (exclusively $S$. analis/ciliata in subtidal shores, cf. Weng 1983) obviously allowed these fish to continue intertidal feeding over the whole tidal cycle (no change in prey composition in fish gut contents was apparent $2 \mathrm{~h}$ before and after LT).

Whether pool occupation actually increases recruit fitness (e.g. mortality per unit of growth) does not rely solely upon energetic benefits through continuous food intake. Other factors must be considered when discussing the nursery value of these microhabitats, 
particularly as they are occupied on a temporary basis only. Usually, young fish in tidepools are thought to experience significantly lower predation pressure than in subtidal areas (e.g. van der Veer \& Bergman 1986, Kneib 1994, Gibson et al. 2002). Here too, we have reason to assume that predation risk to new whiting recruits is of lesser importance when occupying tidepools for a significant part of the tidal cycle. Most other pool-dwelling carnivores were small early life stages themselves and were therefore probably competitors rather than predators. Birds, which may be important predators elsewhere (e.g. Mahon \& Mahon 1994), also did not appear to pose a serious threat. If they were observed foraging at any of the study locations, they were usually concentrated in either exceptionally large pools or areas close to the LT mark, where larger fish may be more common. The only potential whiting predators in investigated pools appeared to be adolescent and adult gobiids (authors' unpubl. data), but it remains to be examined to what extent such predation occurs. In subtidal shores, in contrast, many predatory species are abundant and known to prey on small fish (e.g. Sphyraena obtusata, Pelates sexlineatus and Platycephalus spp.; Johnson 1999, Froese \& Pauly 2008). Presumably, the most significant predation pressure to young whiting is posed by the juveniles of such species. During a preliminary experiment at MBRS, we observed that later juvenile whiting (80 to $100 \mathrm{~mm}$ ) prey very efficiently upon their larval and early juvenile counterparts $\leq 30 \mathrm{~mm}$.

Water temperature in tidepools could be another very important nursery factor. In Botany Bay, $1000 \mathrm{~km}$ south of the study area, repeated length measurements of recently settled Sillago ciliata cohorts (Smith \& Sinerchia 2004) indicated a temperature-dependent growth rate $(G)$ of $0.19 \% L \mathrm{~d}^{-1}{ }^{\circ} \mathrm{C}^{-1}$. Extrapolating their data, we estimate that new Sillago recruits in the study area could increase diel growth rates under thermal conditions in subtidal areas $\left(22^{\circ} \mathrm{C}, G \approx 1.48 \%\right)$ by $66 \%$, if they reside in $5^{\circ} \mathrm{C}$ warmer waters $(G \approx 2.44 \%$ ). Assuming pool residence at $27^{\circ} \mathrm{C}$ for $6 \mathrm{~h} \mathrm{~d}^{-1}$ (presumably a conservative estimate), post-settlement metamorphosis could consequently be completed roughly 1 wk earlier. However, temperature preferences and limitations of investigated young sillaginids are unknown, as is the energetic demand necessary to support such temporary increases in growth rate. Nonetheless, as for Girella nigricans (Norris 1963), thermotaxis may drive new whiting recruits to remain high on the shore and occupy tidepools as 'aquatic incubators' (sensu Gosline 1965). To complete metamorphosis, it is possible that high temperatures and low predation pressure are more important than continuous feeding for pool-dwelling whiting (cf. Keefe \& Able 1993 regarding flounder).

\section{Implications for resource managers and future research}

We conclude that permanent intertidal residence is likely to represent an integral and beneficial component of Sillago recruitment on mudflats in Moreton Bay. We end this discussion by briefly addressing some aspects of greater relevance. The global commercial catch of sillaginid whiting has risen from 1000-2000 t up to 1969 to about $39000 \mathrm{t}$ in 2006 (FAO fisheries database: www.fao.org/fi), and a similar or higher catch by artisanal and recreational fisheries can be presumed. Despite the low vulnerability attributed to most sillaginids (Froese \& Pauly 2008), growing fishing pressure combined with increased elimination, fragmentation and pollution of easily accessed aquatic habitats may pose a threat to some populations. We therefore advise resource and conservation managers to consider largely structureless mud- and sandflats as primary nursery zones for Sillago whiting; presumably, this is valid for more than the 3 species investigated here (authors' pers. obs.). However, our samples do not represent all habitats that can be occupied at settlement, and any related future research activity should therefore include other (e.g. estuarine) habitats where young sillaginids are very common. An important task remaining will be to address density dependence of new Sillago recruits. Given some published indication that fish densities in pools of the study area are regionally stable (Meager et al. 2005), it would be prudent to explore whether intertidal settlement dampens year-class strength variations, such as for plaice in the Wadden Sea (van der Veer 1986). Unfortunately, any such investigation will confront problems of accurately identifying different Sillago species. Using genetic methods to supplement morphology-based identifications retrospectively, we can confirm that the settling larvae of each previously identified species occupy tidepools. However, while larval $S$. maculata can be discriminated from $S$. analis and $S$. ciliata using affordable electrophoretic methods to fingerprint amplified DNA sequences of the mitochondrial cytochrome oxidase subunit I (COI), neither barcoding of COI nor of the faster evolving control region (d-loop) suffices to discriminate S. analis and S. ciliata (authors' unpubl. data).

Acknowledgements. We thank M. Sandersfeld, V. Schrameyer, N. Wilke, and the staff at MBRS for excellent assistance with laboratory work, fish sampling and preparation of experiments. S. Blomberg is thanked for statistical advice. We appreciate the support of W. Loh and J. Johnson with the identification of whiting species. Grant D/06/49937 to N.C.K. by the German Academic Exchange Service (DAAD) is gratefully acknowledged. Valuable comments by the responsible editor and 3 anonymous reviewers helped to improve an earlier version of the manuscript. 


\section{LITERATURE CITED}

Beck MW, Heck KL Jr, Able KW, Childers DL and others (2001) The identification, conservation, and management of estuarine and marine nurseries for fish and invertebrates. Bioscience 51:633-641

Beckley LE (1985) The fish community of East Cape tidal pools and an assessment of the nursery function of this habitat. S Afr J Zool 20:21-27

Beckley LE (2000) Species composition and recruitment of tidal pool fishes in KwaZulu-Natal, South Africa. Afr Zool 35:29-34

Berghahn R (1983) Untersuchungen an Plattfischen und Nordseegarnelen (Crangon crangon) im Eulitoral des Wattenmeeres nach dem Übergang zum Bodenleben. Helgol Mar Res 36:163-181

Birt MJ, Tibbetts IR (2007) Temperature changes in the tidal excursion front and surface sediment of a subtropical mudflat in autumn. J Sea Res 58:113-119

Bray JR, Curtis JT (1957) An ordination of the upland forest communities of southern Wisconsin. Ecol Monogr 27: 325-349

Bromley PJ (1994) The role of gastric evacuation experiments in quantifying the feeding rates of predatory fish. Rev Fish Biol Fish 4:36-66

Burchmore JJ, Pollard DA, Middleton MJ, Bell JD, Pease BC (1988) Biology of four species of whiting (Pisces: Sillaginidae) in Botany Bay, New South Wales. Aust J Mar Freshw Res 39:709-727

Caselle JE (1999) Early post-settlement mortality in a coral reef fish and its effect on local population size. Ecol Monogr 69:177-194

Cortes E (1997) A critical review of methods of studying fish feeding based on analysis of stomach contents: application to elasmobranch fishes. Can J Fish Aquat Sci 54:726-738

Coull BC (1999) Role of meiofauna in estuarine soft-bottom habitats. Aust J Ecol 24:327-343

Coull BC, Greenwood JG, Fielder DR, Coull BA (1995) Subtropical Australian juvenile fish eat meiofauna: experiments with winter whiting Sillago maculata and observations on other species. Mar Ecol Prog Ser 125: 13-19

Crowley BG, Tibbetts IR (1996) The diversity of fishes inhabiting bare intertidal pools on two sedimentary shores in Moreton Bay. Proc R Soc Queensl 105:21

> Dahlgren CP, Kellison GT, Adams AJ, Gillanders BM and others (2006) Marine nurseries and effective juvenile habitats: concepts and applications. Mar Ecol Prog Ser 312: 291-295

Froese R, Pauly D (eds) (2008) FishBase. www.fishbase.org

Gibson RN, Yoshiyama RM (1999) Intertidal fish communities. In: Horn MH, Martin KLM, Chotkowski MC (eds) Intertidal fishes: life in two worlds. Academic Press, San Diego, CA, p 264-290

Gibson RN, Robb L, Wennhage H, Burrows MT (2002) Ontogenetic changes in depth distribution of juvenile flatfishes in relation to predation risk and temperature on a shallowwater nursery ground. Mar Ecol Prog Ser 229:233-244

Giere O (1993) Meiobenthology: the microscopic fauna in aquatic sediments. Springer-Verlag, Berlin/Heidelberg

Gosline WA (1965) Vertical zonation of inshore fishes in the upper water layers of the Hawaiian Islands. Ecology 46:823-831

Gunn JS, Milward NE (1985) The food, feeding habits and feeding structures of the whiting species Sillago sihama (Forsskal) and Sillago analis Whitley from Townsville, North Queensland, Australia. J Fish Biol 26:411-427

Heck KL Jr, Hays G, Orth RJ (2003) Critical evaluation of the nursery role hypothesis for seagrass meadows. Mar Ecol Prog Ser 253:123-136

Hellawell JM, Able R (1971) A rapid volumetric method for the analysis of the food of fishes. J Fish Biol 3:29-37

Hernández CE, Neill PE, Pulgar JM, Ojeda FP, Bozinovic F (2002) Water temperature fluctuations and territoriality in the intertidal zone: two possible explanations for the elevational distribution of body size in Graus nigra. J Fish Biol 61:472-488

Hyndes GA, Platell ME, Potter IC (1997) Relationships between diet and body size, mouth morphology, habitat and movements of six sillaginid species in coastal waters: implications for resource partitioning. Mar Biol 128: 585-598

Johnson JW (1999) Annotated checklist of the fishes of Moreton Bay, Queensland, Australia. Mem Queensl Mus 43: 709-762

Keefe M, Able KW (1993) Patterns of metamorphosis in summer flounder, Paralichthys dentatus. J Fish Biol 42: 713-728

Kneib RT (1994) Spatial pattern, spatial scale, and feeding in fishes. In: Stouder DJ, Fresh KL, Feller RJ (eds) Theory and application in fish feeding ecology. University of South Carolina Press, Columbia, SC, p 171-185

> Laegdsgaard P, Johnson C (2001) Why do juvenile fish utilise mangrove habitats? J Exp Mar Biol Ecol 257:229-253

Mahon R, Mahon SD (1994) Structure and resilience of a tidepool fish assemblage at Barbados. Environ Biol Fishes 41:171-190

Mangubhai S, Greenwood JG, Tibbetts IR (1998) Meiofaunal selectivity in the diet of juvenile whiting (Sillago maculata Quoy and Gaimard) from Moreton Bay. In: Tibbetts IR, Hall NJ, Dennison WC (eds) Moreton Bay and catchment. School of Marine Science, The University of Queensland, Brisbane, p 473-474

> McCormick MI, Makey L, Dufour V (2002) Comparative study of metamorphosis in tropical reef fishes. Mar Biol 141: 841-853

McCune B, Mefford MJ (1999) PC-ORD for Windows: multivariate analysis of ecological data. MjM Software, Gleneden Beach, OR

McKay RJ (1992) Sillaginid fishes of the world (Sillaginidae). FAO Species Catalogue, Vol 14. FAO, Rome

McLean JL (1971) The food and feeding of winter whiting (Sillago maculata Quoy and Gaimard) in Moreton Bay. Proc Linn Soc NSW 98:87-92

> Meager JJ, Williamson I, King CR (2005) Factors affecting the distribution, abundance and diversity of fishes of small, soft-substrata tidal pools within Moreton Bay, Australia. Hydrobiologia 537:71-80

Mumby PJ, Edwards AJ, Arias-Gonzalez JE, Lindeman KC and others (2004) Mangroves enhance the biomass of coral reef fish communities in the Caribbean. Nature 427:533-536

Norris KS (1963) The functions of temperature in the ecology of the percoid fish Girella nigricans (Ayres). Ecol Monogr $33: 23-62$

Robertson AI (1977) Ecology of juvenile King George whiting Sillaginodes punctatus (Cuvier \& Valenciennes) (Pisces: Perciformes) in Western Port, Victoria. Aust J Mar Freshw Res 28:35-43

Rombough PJ (1997) The effects of temperature on embryonic and larval development. Soc Exp Biol Semin Ser 61:177-223

Sheaves M, Baker R, Johnston R (2006) Marine nurseries and effective juvenile habitats: an alternative view. Mar Ecol Prog Ser 318:303-306 
Smith KA, Sinerchia M (2004) Timing of recruitment events, residence periods and post-settlement growth of juvenile fish in a seagrass nursery area, south-eastern Australia. Environ Biol Fishes 71:73-84

Thorisson K (1994) Is metamorphosis a critical interval in the early life of marine fishes? Environ Biol Fishes 40:23-36

Tibbetts IR, Hall NJ, Dennison WC (1998) Moreton Bay and catchment. School of Marine Science, The University of Queensland, Brisbane

van der Veer HW (1986) Immigration, settlement, and density-dependent mortality of a larval and early postlarval 0-group plaice (Pleuronectes platessa) population in the western Wadden Sea. Mar Ecol Prog Ser 29:223-236

Editorial responsibility: Robert Feller, Columbia, South Carolina, USA van der Veer HW, Bergman MJN (1986) Development of tidally related behaviour of a newly settled 0-group plaice (Pleuronectes platessa) population in the western Wadden Sea. Mar Ecol Prog Ser 31:121-129

Victor BC (1986) Larval settlement and juvenile mortality in a recruitment-limited coral reef fish population. Ecol Monogr 56:145-160

Weng HT (1983) Identification, habitats and seasonal occurrence of juvenile whiting (Sillaginidae) in Moreton Bay, Queensland. J Fish Biol 23:195-200

- Werner EE, Gilliam JF (1984) The ontogenetic niche and species interactions in size-structured populations. Annu Rev Ecol Syst 15:393-425

Submitted: March 17, 2008; Accepted: February 26, 2009

Proofs received from author(s): April 27, 2009 